\title{
Estimate zebra mussel veliger density from the riverbanks, lotic stretch and reservoir, in two Mediterranean rivers (E Spain)
}

\author{
Javier Morales $^{1, *}$, Miguel Lizana ${ }^{1}$, Fabio Flechoso ${ }^{2}$, Gina M. Bejarano ${ }^{1,2}$, and Ana I. Negro ${ }^{2}$ \\ ${ }^{1}$ Department of Animal Biology Salamanca University, 37007 Salamanca, Spain \\ 2 Department of Ecology, Salamanca University, 37007 Salamanca, Spain
}

\begin{abstract}
Larval detection is the most commonly used procedure for monitoring the presence of Zebra mussel, Dreissena polymorha. Different filtering techniques carried out on the banks of the Ebro (EB) and Júcar (JU) rivers (Eastern Spain) in different water conditions are compared. Low volume water filtration from the banks is a method sensitive enough to detect variations in larval density due to water temperature and flow rates. The EB densities were lower and related to the temperature of the water. In JU, different spawning strategies and a much extended period of larval releasing into the water occurred in two consecutive years. The presence of larvae in both rivers was constant for many months of the year, during which various reproductive cycles occurred, facilitated by high water temperatures during mid-spring to late fall. Shoreline surveys can be easily used for allowing the early warning of the presence of this dangerous invasive species, mitigating damages and preventing its spread into new areas. However, it is important to choose a suitable location for capturing the larvae on the banks of reservoirs and in flowing rivers.
\end{abstract}

Keywords: Freshwater invasion / veliger monitoring / larvae sampling method / riberbanks / Mediterranean rivers

Résumé - Estimer la densité des larves véligère de la moule zébrée à partir des rivages, un segment lotique et un réservoir, dans deux rivières méditerranéennes (Est de l'Espagne). La détection larvaire est la procédure la plus couramment utilisée pour surveiller la présence de la moule zébrée, Dreissena polymorha. Différentes techniques de filtrage réalisées sur les rives de l'Èbre et du Júcar (Est de l'Espagne) dans différentes conditions de rivière et d'eau stagnante (réservoirs) sont comparées. La filtration de l'eau à faible volume à partir des berges est une méthode suffisamment sensible pour détecter les variations de densité larvaire dues à la température de l'eau et aux débits. La présence de larves dans les deux rivières a été constante pendant de nombreux mois de l'année, au cours desquels divers cycles de reproduction se sont produits, facilités par les températures élevées de l'eau du milieu du printemps à la fin de l'automne. Les relevés littoraux peuvent être facilement utilisés pour permettre l'alerte précoce de la présence de cette espèce envahissante dangereuse, atténuant ainsi les dommages et empêchant sa propagation dans de nouvelles zones. Cependant, il est important de choisir un endroit approprié pour capturer les larves sur les rives des réservoirs et dans les cours d'eau.

Mots clés: Invasion en eau douce / surveillance des véligères / méthode d'échantillonnage des larves / rivage / rivière Méditerranéenne

\section{Introduction}

The alteration of aquatic ecosystems produced during biological invasions by non-native invasive species (NIS) can be quite serious and rapidly occurring (Savini et al., 2010). NIS are considered one of the main problems in biodiversity conservation (Lowe et al., 2000; Hulme, 2007; Keller et al., 2011) and, in Europe, are able to rapidly spread throughout the continent (EEA, 2012).

\footnotetext{
${ }^{*}$ Corresponding author: mormarja@usal.es
}

A good example of such expansion is the zebra mussel Dreissena polymorpha (Pallas, 1771), which has spread during the last decade throughout the Mediterranean basins. D. polymorpha populations in the lower section of the Ebro River (E Spain) have been studied since 2001, where this species has greatly expanded in reservoirs used for the production of electricity (Araujo et al., 2010; Sanz-Ronda et al., 2013). The mechanisms of dispersion of the zebra mussel through agricultural irrigation systems, fishing activities and sailing have been studied (Durán and Anadón, 2008), as well as the application of possible control methods and the 
dispersion of this species (Bernat et al., 2010). Initial data from the lotic areas of the middle Ebro are presented in Morales et al. (2013) regarding a multi-xenobiotic section containing a large number of aquatic NIS (Rodríguez et al., 2017). Expansion within the Ebro basin (Durán et al., 2010) has been shown to be a serious ecological and economic problem, owing to its severe negative effects on ecosystems and infrastructures, especially with respect to drinking water abstraction and the production of electricity (Pérez and Chica, 2010; Durán et al., 2012). The lower Ebro has been a central area for the rapid dispersion of this species towards the rest of the basin (Oscoz et al., 2010) and other Mediterranean basins.

The spread of D. polymorpha towards the Júcar basin began in 2005 (Sitjar Reservoir, Araujo, 2007; and Forata Reservoir, MARM, 2009). Although the main riverbed of the Júcar has been invaded since 2014 (CHJ, 2015), the presence was only detected in the summer of 2015 , within the system of concatenated reservoirs of the Júcar canyon (Naranjero-Cortes II-Contreras). Since then, this species has greatly expanded to lower areas, originating from irrigation infrastructures (Araujo, 2006; CHJ, 2017).

The dreissenid life cycle includes a planktonic larval stage, which permits the animal to disperse downstream from reservoirs in areas with slow-moving currents (Stoeckel et al., 2004; Lucy et al., 2008; Olson et al., 2018). In addition, a closely linked relationship between the growth of the species and the physicochemical properties of water has been described, especially temperature which conditions its metabolism, gametogenesis and embryogenesis (Nichols, 1993, 1996; Nichols and Black, 1994; Ackerman et al., 1994; Armistead, 1995).

The minimum water temperature for adult survival is between $0-2{ }^{\circ} \mathrm{C}, 5-8{ }^{\circ} \mathrm{C}$ for feeding, $10{ }^{\circ} \mathrm{C}$ for growth and $12-14{ }^{\circ} \mathrm{C}$ for reproduction. It has also been experimentally determined that the upper survival threshold is between 30 and $32{ }^{\circ} \mathrm{C}$, although the animal becomes stressed at temperatures above $25-28{ }^{\circ} \mathrm{C}$ (Nichols, 1993; Griebeler and Seitz, 2007). Other physicochemical characteristics of water, such as current velocity, dissolved oxygen, alkalinity, calcium and phosphorus content, dissolved matter or in suspension, are important for understanding the distribution of the species and colonization patterns in shallow areas and deep reservoirs. All of these factors act together, controlling the breeding seasons and the biological success of the species, according to the climatology of each year (Karatayev et al., 1998; Jones and Ricciardi, 2005; Naddafi et al., 2011).

The optimal temperature range for feeding, the increase of body size and gametogenesis is between 8 and $26^{\circ} \mathrm{C}$ (Sprung, 1987, 1989; Schneider, 1992; Mackie and Schloesser, 1996). Therefore, this animal is an eurythermic species; although each stage of the life cycle has optimal conditions, within a minimum threshold of $12-14{ }^{\circ} \mathrm{C}$, that allow the time points for releasing gametes into the water, producing a planktonic larval population (the dispersive phase) (Sprung, 1987; Armistead, 1995; Mackie and Schloesser, 1996), to be predicted. The interannual variability of this time point is essential for monitoring lotic areas and deep reservoirs with thermal stratification, as this information can lead to an early warning regarding the onset of reproduction and mark the start of monitorization of the larvae.

Zebra mussels prefer slightly basic waters and develop, with some difficulty, in waters with low levels of mineralization. These conditions allow the potential for invading natural aquatic environments to be estimated (Hincks and Mackie, 1997; Cohen and Wenstein, 2001). Also, it must be taken into account that D. polymorpha is an eurioic species with respect to many environmental factors, highly tolerant and with great reproductive potential. Therefore, even small colonies or isolated adult specimens can survive in conditions of low dissolved oxygen (Yu and Culver, 1999) and in suboptimal environments. In the Ebro, as well as the Júcar River, water has optimal physicochemical and thermal characteristics for the reproduction of this species during long periods of the year (USAL, 2014, 2018).

The "Zebra mussel control strategy in Spain" (MARM, 2009) set up a network of control points for early detection, which is vital for minimizing damage. From these strategic points, the presence of the larvae is monitored and restriction measures are implemented with respect to sailing, as well as the preventive disinfection of tools and boats in affected riverbeds. Moreover, plankton samples are collected during the summer (vertical trawls in epilimnion) and monitoring the colonization of submerged test-cores in deep-water buoys of large reservoirs are monitored. However, until now, the possibility of larval sampling in banks has not been explored, either in lotic areas or in shallow channels and reservoir banks, the preferred locations of this species.

The aim of this study is to determine larval density in two river dynamics and to design a simple early warning system for analyzing water samples taken from river banks sensitive enough to detect low densities. The aim was also to determine the duration of the spawning period in relation to the physicochemical properties of the water (mainly temperature) and rate of flow, and to predict the moment of maximum larval density in two very different fluvial environments.

\section{Material and methods}

The two study areas are located in Mediterranean rivers of the Iberian Peninsula: (1) on the riverbanks of the Ebro (EB) surrounding area to the Castejón combined cycle power plant (CCPP) (ETRS89 30N projection: latitude $42^{\circ} 10^{\prime} 19^{\prime \prime} \mathrm{N}$; longitude $1^{\circ} 40^{\prime} 46^{\prime \prime} \mathrm{W}$; altitude 268 m.s.a.l.) in Navarra (Northeast Spain); and (2) in the waters of the Cortes II reservoir in the Júcar (JU) canyon (latitude $39^{\circ} 14^{\prime} 52^{\prime \prime} \mathrm{N}$; longitude $0^{\circ} 56^{\prime} 03^{\prime \prime} \mathrm{W} ; 330 \mathrm{~m}$.s.a.l.) next to La Muela hydroelectric power plant (HPP) in Valencia (Eastern Spain). In Castejón, a sampling point was placed next to the gauging station of the Ebro Hydrographic Confederation (CHE), where water temperature and flow data were obtained. Likewise, data were obtained on the Cortes II reservoir from stations within the official network of the Júcar Hydrographic Confederation $(\mathrm{CHJ})$ in Cofrentes and Alcalá del Júcar (Fig. 1).

A lotic area with a strong current, successive rapids, and braided and anastomosed stretches with gravel substrate and eupotamic dynamics was selected in the Ebro River (Fig. 1) (Petts and Amoros, 1996). This area had been colonized several years previously and had received larvae originating from upstream waters. In the Júcar River, a recently colonized reservoir was selected, which works as a continuously flowing fluvial lake located in a canyon of limestone rocks; however, in this case no larvae came from up-stream waters. 


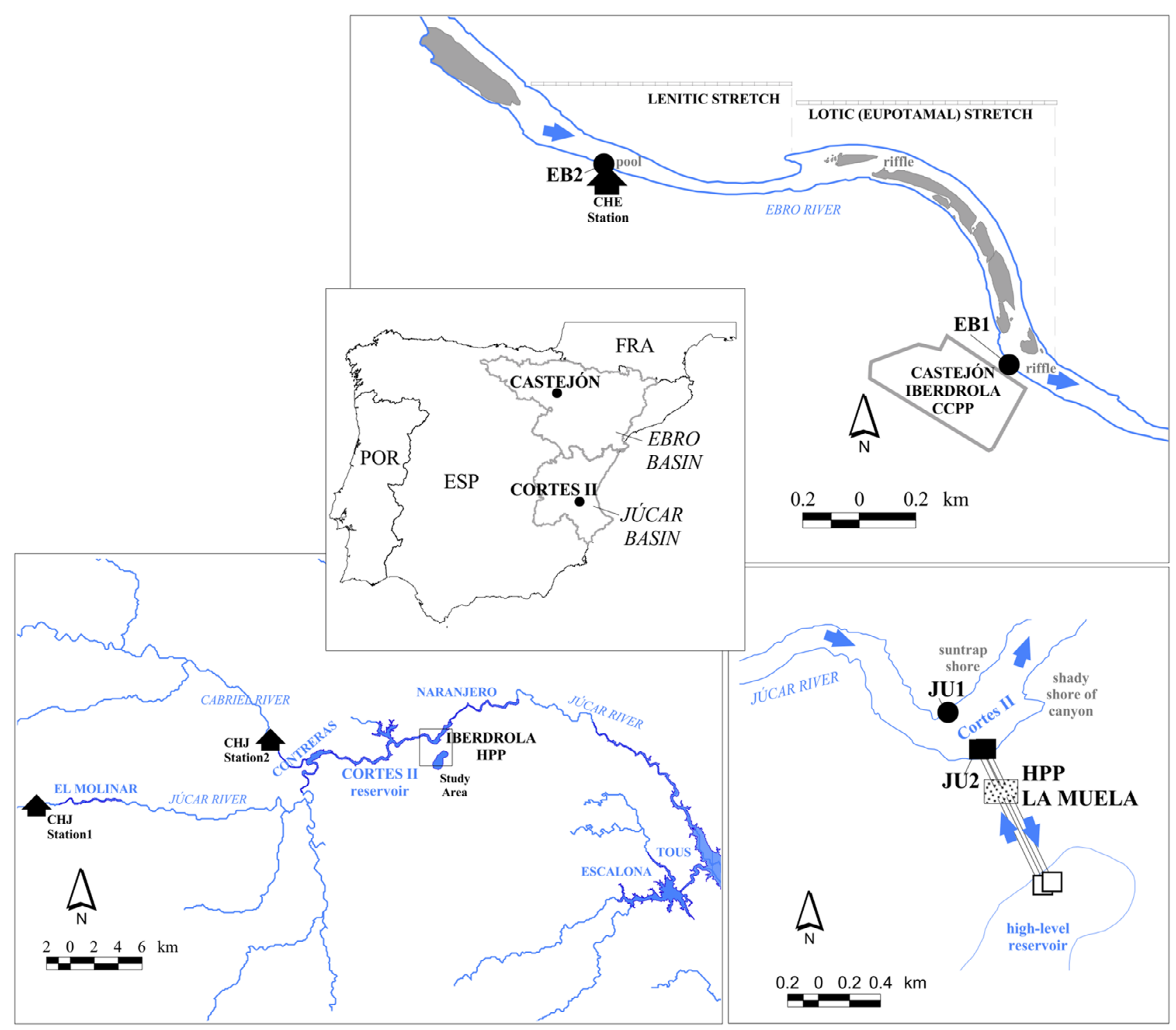

Fig. 1. Location of the study areas in the Iberian Peninsula, including details of the Ebro riverbanks (Castejón de Ebro, Navarra) and Cortes II reservoir in the Júcar canyon (Cortes de Pallás, Valencia). The locations of the power stations affected by the zebra mussel are also provided. CCPP, combined cycle power-plant; HPP, hydro power-plant.

The species were monitored in Spain by counting larval stages in plankton samples that were collected by vertical trawling of the epilimnetic area of reservoirs. Also, the optimization of a rapid quantification procedure using a microscope has also been proposed as a complementary objective by comparing experimental techniques involving partial counting ( 3 aliquots in the concentrated sample) versus counting the total filtered volume.

Larval development was monitored at two sampling stations (EB1 and EB2) located near a breakwater on the right bank of the Ebro River (Fig. 1). E1 was located upstream in a deep section of water with a laminar flow, and EB2 was located in a stretch with a strong thermal current (eupotamal dynamic) approximately $2 \mathrm{~km}$ downstream, in the protection breakwater of the CCPP. In the fluvial canyon of the Júcar River samples were collected on the Cortes II reservoir (JU1 and JU2), under very different isolation and turbulence conditions. JU1 was located in a shallow creek near the sunny side of the bank and JU2 was located near the shady bank to the water catchment for the HPP (Fig. 1).

During 2010, 20 L of water was filtered (Met-1) at the riverbanks, and this volume was also used for other sample collections. In addition, another method was tested that involved installing a submerged net into the Ebro riverbed for 1 min (Met-2). The larvae were always captured around solar noon in order to reduce the influence of migrations in the deep waters of lenitic areas. The water was filtered using plankton mesh, $30 \mathrm{~cm}$ in diameter, fitted with a ${ }^{\circledR}$ Nitex net with a mesh size of $55 \mu \mathrm{m}$. Each sample was collected in 20-50 ml tubes. The density $(D)$ is expressed in veliger larvae (all stages added) per cubic meter $\left(\mathrm{v} \mathrm{m}^{-3}\right)$. In Ebro the larval density was measured in samples taken at different depths from a blind well ( $8 \mathrm{~m}$ deep) containing larvae using two methods: (1) selectively collecting $20 \mathrm{~L}$ of water in each meter of 
Table 1. Average abundance of planktonic larvae $\left(\mathrm{v} \mathrm{L}^{-1}\right)$ per aliquot at different stages of development throughout the hydrological year and changes in water temperature. More information on variations in the flow rate after reservoirs construction are provided in the Electronic Supplementary Material 1.

\begin{tabular}{|c|c|c|c|c|c|c|c|c|c|c|c|c|c|}
\hline Ebro River - EB & October & November & December & January & February & March & April & May & June & July & August & September & 2010-2013 \\
\hline Average monthly flow $\left(\mathrm{m}^{3} \mathrm{~s}^{-1}\right)$ & 54.7 & 146.1 & 249.5 & 314.4 & 379.7 & 411.0 & 308.3 & 202.3 & 152.3 & 58.8 & 50.5 & 54.5 & 111.82 \\
\hline Historic flow $\left(\mathrm{m}^{3} \mathrm{~s}^{-1}\right)$ & 1987.5 & 3583.0 & 4177.0 & 3958.0 & 3236.0 & 3380.0 & 2115.0 & 2495.8 & 2457.6 & 530.0 & 1115.4 & 740.0 & \\
\hline $\begin{array}{l}\text { Average monthly water } \\
\text { temperature }\left({ }^{\circ} \mathrm{C}\right)\end{array}$ & 15.2 & 13.1 & 6.8 & 7.3 & 7.5 & 11.1 & 15.6 & 15.6 & 18.9 & 22.8 & 24.3 & 20.3 & 12.4 \\
\hline$d$ & 4 & 2 & 3 & 2 & 2 & 4 & 6 & 14 & 15 & 10 & 3 & 5 & 70 \\
\hline D-veliger & 0.0 & 0.0 & 0.0 & 0.0 & 0.0 & 0.07 & 1.01 & 7.3 & 2.6 & 0.4 & 0.3 & 0.2 & $52.74 \%$ \\
\hline V-veliger & 0.1 & 0.0 & 0.0 & 0.0 & 0.0 & 0.0 & 0.4 & 3.3 & 2.2 & 0.6 & 0.8 & 0.1 & $38.06 \%$ \\
\hline P-veliger & 0.0 & 0.0 & 0.0 & 0.0 & 0.0 & 0.0 & 0.08 & 1.4 & 0.5 & 0.2 & 0.3 & 0.0 & $9.20 \%$ \\
\hline Júcar River - JU & October & November & December & January & February & March & April & May & June & July & August & September & 2016-2017 \\
\hline Average monthly flow $\left(\mathrm{m}^{3} \mathrm{~s}^{-1}\right)$ & 6.8 & 3.8 & 4.0 & 4.7 & 5.9 & 5.7 & 5.7 & 6.3 & 9.4 & 16.4 & 12.4 & 8.6 & 6.6 \\
\hline Historic flow $\left(\mathrm{m}^{3} \mathrm{~s}^{-1}\right)$ & 116.6 & 303.3 & 173.6 & 279.5 & 332.7 & 345.2 & 236.8 & 184.8 & 160.7 & 109.1 & 105.6 & 81.4 & \\
\hline $\begin{array}{l}\text { Average monthly water } \\
\text { temperature }\left({ }^{\circ} \mathrm{C}\right)\end{array}$ & 21.7 & 18.9 & 12.2 & 10.0 & 10.7 & 12.0 & 16.5 & 19.9 & 23.5 & 25.2 & 25.9 & 24.5 & 16.4 \\
\hline$d$ & 3 & 2 & 2 & 2 & 1 & 1 & 1 & 2 & 6 & 4 & 3 & 4 & 31 \\
\hline D-veliger & 3.1 & 3.5 & 0.0 & 0.0 & 0.0 & 0.0 & 4.0 & 8.6 & 41.6 & 28.6 & 11.1 & 10.2 & $43.74 \%$ \\
\hline V-veliger & 2.8 & 2.0 & 0.0 & 0.0 & 0.0 & 0.0 & 4.7 & 4.0 & 35.6 & 29.0 & 15.3 & 15.8 & $42.14 \%$ \\
\hline P-veliger & 2.4 & 0.0 & 0.0 & 0.0 & 0.0 & 0.0 & 7.0 & 0.4 & 12.9 & 5.5 & 2.7 & 2.0 & $14.12 \%$ \\
\hline
\end{tabular}

$d$, sampling number days.

Table 2. Correlation between water temperature and river flow values with the larval density of Dreissena polymorpha at different phases of metamorphosis.

\begin{tabular}{llll}
\hline & & $\begin{array}{l}\text { Average monthly } \\
\text { temperature }\left({ }^{\circ} \mathrm{C}\right)\end{array}$ & $\begin{array}{l}\text { Average monthly } \\
\text { flow }\left(\mathrm{m}^{3} \mathrm{~s}^{-1}\right)\end{array}$ \\
\hline Castejón & D-veliger & $R: 0.70^{*}$ & $R:-0.18$ n.s. \\
2010-2014 & V-veliger & $R: 0.81^{*}$ & $R:-0.50 \mathrm{n} . \mathrm{s}$. \\
& P-veliger & $R: 0.66^{*}$ & $R:-0.28 \mathrm{n} . \mathrm{s}$. \\
Cortes II & D-veliger & $R: 0.88^{*}$ & $R: 0.75^{*}$ \\
2016-2017 & V-veliger & $R: 0.87^{*}$ & $R: 0.77^{*}$ \\
& P-veliger & $R: 0.71^{*}$ & $R: 0.69^{*}$ \\
\hline
\end{tabular}

$R$, spearman correlation test; n.s., $p$-value $>0.05 ; \stackrel{*}{p}<0.05$.

depth of the blind well; and (2) using a water pump system $\left(0.8-1 \mathrm{~m}^{3}\right)$ with water filtration from the bottom of the well (Met-3) into a 50- and 30- $\mu \mathrm{m}$ mesh plankton net.

The larval counts carried out with a microscope were done using a concentrated sample of dead larvae fixed with $2 \%$ formalin drops and stored in $70^{\circ}$ ethanol. For the determination, larval density was carried out in the port-column using 3-ml aliquots following the plankton Utermöhl technique (1958). They were visually identified using the Nichols and Black (1994) key with a Nikon-Eclipse E2000-POL (crosspolarization) microscope (Johnson, 1995), always using 100× increases in the counts.

Two microscopic counting techniques were compared in order to ensure the accuracy of the results. First, partial counts were carried out, using three replicates of 3-ml aliquots (Met1), which meant that between $18 \%$ and $45 \%$ of the concentrated sample was being analyzed. Then, a total count (Met2) was done using the necessary number of replicates until $10 \%$ of the concentrated sample was examined. In all cases, the aliquots were taken from samples that had been homogenized by circular and smooth agitation so as not to break the shells. This was also done to maintain the probability of detection of each larva in the whole process, and the aliquot was replaced. A count was done on each sample three times to avoid inaccurate results which may have been arisen due to the successive dilutions and to ensure the accuracy of the calculation method.

\section{Results}

Zebra mussels in Ebro spawned for an average of $74 \pm 35.2$ days at beginning of summer and develop in a unimodal release, similar to other populations. However, in Júcar a much longer spawning period was detected starting from the beginning of spring (185 \pm 27.7 days), where the animals developed in a multimodal release until mid-autumn. The annual average temperature of the water was $4{ }^{\circ} \mathrm{C}$ warmer (Tab. 1) in JU. None of the filtered samples collected manually by the shore contained pediveliger larvae at the "plantigrade" stage or Corbicula fluminea larvae, although both were present at the two sampling points. Significant correlations were found between the density of the different larval phases with the monthly average water temperature in both rivers (Tab. 2); however, higher correlation values found between temperature and the V-veliger stages. The samples collected from EB were positive for the presence of larvae when the temperature of the water ranged between 15.6 and $24.3^{\circ} \mathrm{C}, 15.5$ and $25.9{ }^{\circ} \mathrm{C}$ in $\mathrm{JU}$, and in both rivers once the temperature had reached $14^{\circ} \mathrm{C}$. Severe changes in hydrodynamics, current and past flows, caused by the construction of large reservoirs on both rivers are shown in the Electronic Supplementary Material 1. 

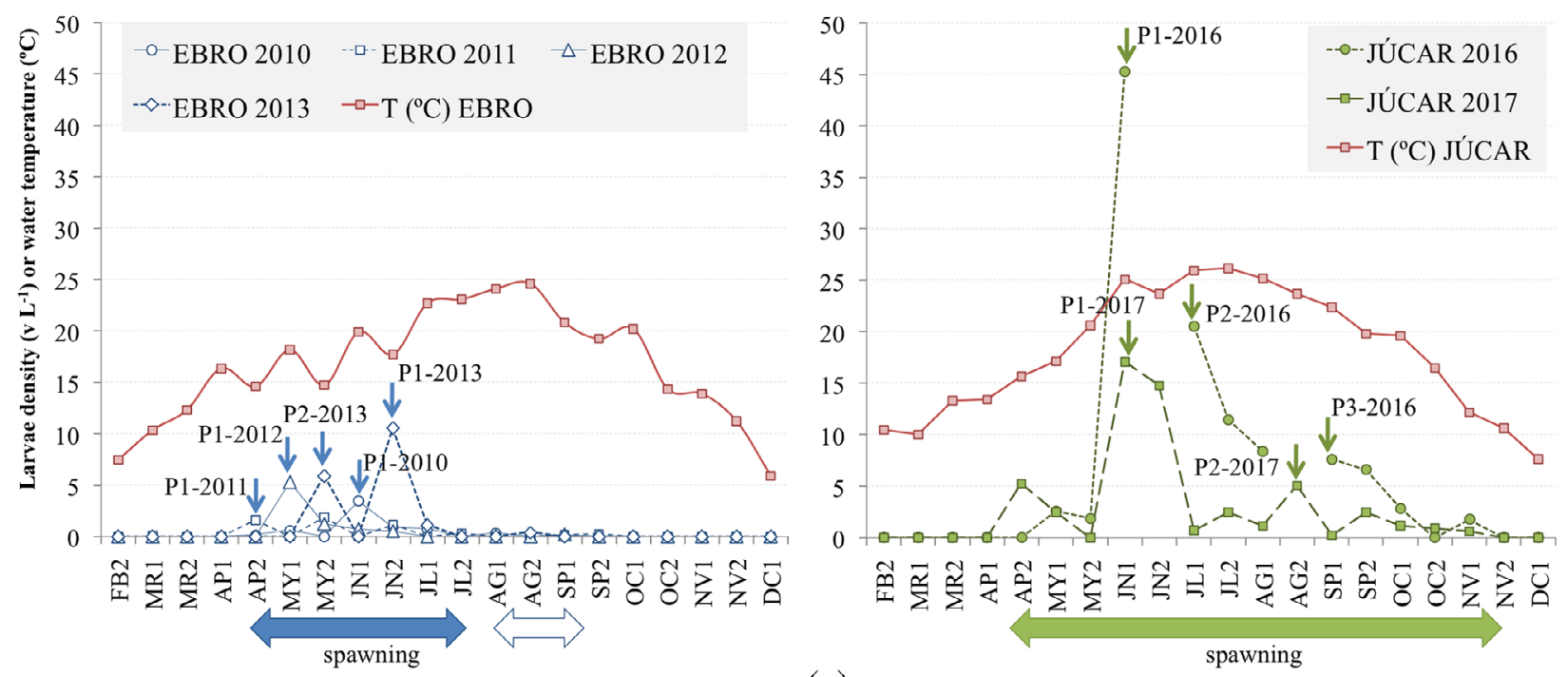

(a)

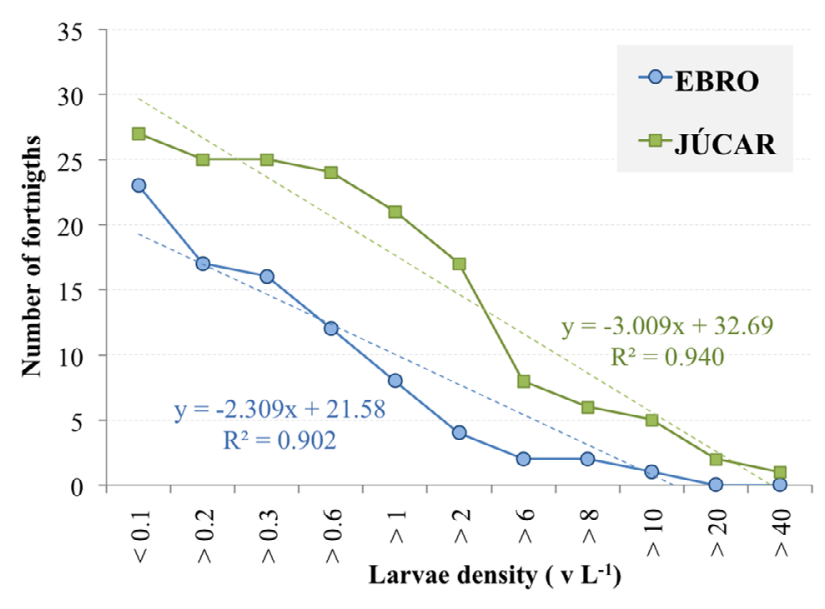

(b)

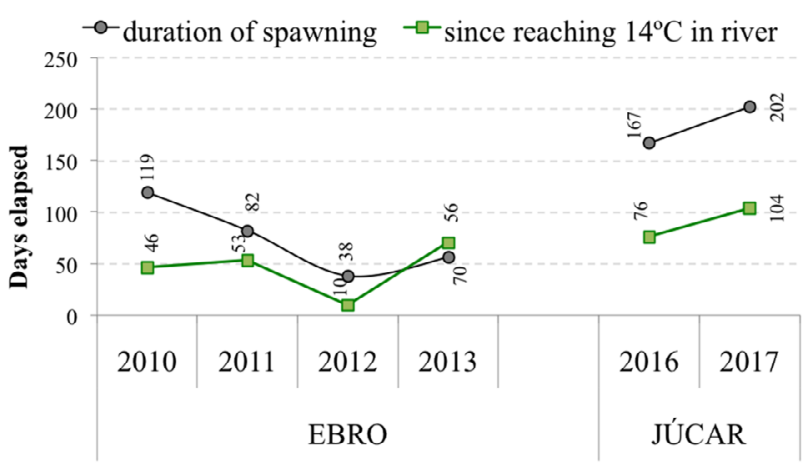

(c)

Fig. 2. (A) Larvae densities found in Ebro river (left) and the Cortes II reservoir (right); the spawning period and larval peaks are indicated for each study period. (No data June and August 2016). (B) Relationship between larval density and the duration of each breeding period (in weeks) for both study areas. (C) Duration of the spawning season and the time period elapsed from the first positive larvae sample until the water reaches $14{ }^{\circ} \mathrm{C}$.

\subsection{Larvae sampling from the riverbanks in lotic eupotamal stretch - Ebro}

At points EB1 and EB2, maximum values were found from the end of May to the beginning of June, according to inter annual variability; although in 2013 there was a second spawning phase a few weeks later (Fig. 2A). The maximum larval peaks in the water were recorded during the second half of June, and no larvae were detected in October during the four study years. Lower densities were found at EB1 $\left(D_{\max }\right.$ : $2.4 \mathrm{vL}^{-1}$ in 2012) than at point EB2, which had a faster current $\left(D_{\max }: 10.55 \mathrm{vL}^{-1}\right.$ in 2012). Both maintained detectable densities $\left(0.1 \mathrm{vL}^{-1}\right)$ on average for six 2-week periods per year, although in 2010 there was delayed spawning during eleven 2-week periods. Values greater than $1 \mathrm{vL}^{-1}$ were maintained during two 2-week periods and a maximum peak $\left(>10 \mathrm{vL}^{-1}\right)$ was only recorded once (Fig. 2B). Larval densities tended to increase throughout the four study years and in both monitoring stations.

\subsection{Other sampling methods in the Ebro}

During the peak of spawning in 2012, greater larval density values were obtained at the surface of the water in the catchment well (see Met1 in Methods) $(57.7 \%-84.6 \%$ in the first meter) than at the bottom of the well, i.e., at a depth of $8 \mathrm{~m}$, with significant differences (Wilcoxon $\mathrm{Z}$ test: $2.27, p<0.05$ ). Also, the values obtained from samples collected from the bottom (see Methods) were quite different from those obtained from the river, during both periods of low density (Met3: 0.001 vs. P2: $\left.0.11 \mathrm{vL}^{-1}\right)$ and spawning peaks $\left(0.02\right.$ vs. $\left.0.17 \mathrm{vL}^{-1}\right)$. This method accumulates a $\times 12$ error factor for larval density determinations, and is inoperative because of the large amount 
of mineral particles carried by the Ebro flow. The effectiveness of the Met 2 was also compared to the procedure that involved submerging a net into the current for $1 \mathrm{~min}$ (speed: $0.5 \mathrm{~ms}^{-1}$ ). The results of this comparison showed significant differences during the spawning peak and during two subsequent days, at which time the densities becoming progressively lower (Met2: 2.19, 0.79, 0.21 $\mathrm{vL}^{-1}$ vs. Met1: 2.0, 0.67, $0.16 \mathrm{vL}^{-1}$ ) from 17 May to 27 June.

\subsection{Optimizing larvae counting method}

In the repetitions of total counts of larvae under the microscope and by three aliquots (Tab. 3), values were obtained without significant differences between both methods (Z: 0.44 , n.s. for J1; and Z: 0.47 , n.s. for J2). The average values (n:13) for the total ratio/aliquots were 0.97 and 0.98 , respectively, for both points. The comparison JU1 versus JU2 using both methods on the sampling areas located in the sun and in the shade (Tab. 3 and Fig. 3) did show differences. Data are provided in the Electronic Supplementary Materials 2 and 3.

\subsection{Larvae sampling from the riverbanks in reservoir}

In the Cortes II reservoir (EB), spawning occurred during April to November (Fig. 2A), with the highest amount of larvae being produced in 2017 . The lowest density $\left(0.02 \mathrm{vL}^{-1}\right)$ was found in a sample collected on 11 December. Here, detectable densities were found for more than fifteen 2-week

Table 3. Results obtained using the two techniques to count larvae under microscope.

\begin{tabular}{lll}
\hline & JU2 & JU2 \\
\hline JU1 & 3 Aliquots & Overall \\
overall & $Z: 2.27^{*}$ & $Z: 2.76^{* *}$ \\
3 aliquots & $Z: 2.35^{* *}$ & $Z: 2.84^{* *}$ \\
\hline
\end{tabular}

$Z$, Wilcoxon matched pairs signed rank test; ${ }^{*} p$-value $<0.05 ;{ }^{* *}<0.01$. periods (Fig. 2B) and high densities were found during five 2 -week periods, with a total spawning period of more than 200 days (Fig. 2C) in 2017, and lower densities. There was also a large quantitative difference in larval production between both years, with maximum peaks in the summer of 2016 and several smaller peaks occurring later on until the middle of autumn. In all the samples collected, fewer larvae were recorded in the shaded area of canyon (JU2) than on the sunny side (JU1), average ratio of $1: 2.4$.

Maximum larvae production occurred in the first half of June during both years $\left(D_{\max }: 62.9 \mathrm{vL}^{-1}\right.$ in 2016), and, later on, other high peaks were observed (Fig. 2A), especially in 2017 when the water temperature was higher. Detectable densities were found during 11-16 2-week periods per year, values higher than $10 \mathrm{vL}^{-1}$ during five 2 -week periods, and maximum production peaks $\left(D_{\max }: 20-40 \mathrm{vL}^{-1}\right)$ during 2-week periods in June (Fig. 2B).

\subsection{Changes of larvae density}

It was found during the monitorization of Ebro that the amount of larvae in the water tended to increase at both sampling stations. EB1 station was less sensitive to changes but always had lower density values despite being a lenitic area and a deep river channel (Fig. 3). In Júcar (JU), the values were extremely high even though the arrival of the zebra mussel was more recent. Additionally, higher densities were always measured on the sunny side of the Júcar canyon even though this area was more sensitive to changes. The results of the Friedman ANOVA (F) and Kendall's concordance (CC) tests revealed significant differences between the values obtained from the lotic versus the lenitic stretch (EB1 vs. EB2 F: 4.57; $N=17, \mathrm{df}=1, p=0.03 ;[\mathrm{CC}=0.27, r=0.22])$. Also, highly significant differences were obtained when comparing the sunny and shady sides of the Cortes II reservoir (JU1 vs. JU2 F: 8.06; $N=16, \mathrm{df}=1, p=0.004 ;[\mathrm{CC}=0.50, r=0.47])$.

Maximum larval production always occurred once the water had reached $14^{\circ} \mathrm{C}$, with differences between years and in some cases in successive pulses and different total times, especially in the reservoir. In EB the relation between the average temperature $(x)$ during a 2-week period and the
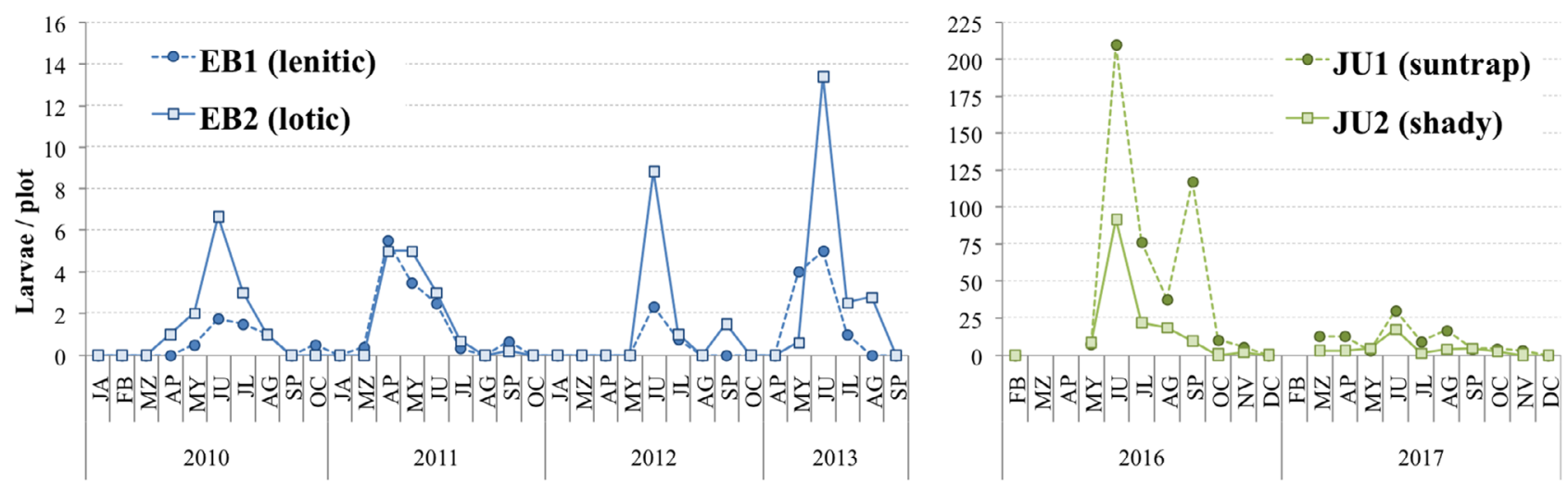

Fig. 3. Variation in larval density determined by microscopic counts in the different topographic areas chosen for filtering water. On the Ebro River for two points $900 \mathrm{~m}$ apart with different dynamics (EB1, EB2) after $5 \mathrm{yr}$ of first detection, and on the opposite banks of the Júcar Canyon (JU1, JU2) after 2 yr. (Different vertical scales). 
production of veliger larvae $(y)$ was found to be of a nonsignificant quadratic polynomial type $(y=255.7+71.14 x$, $r=0.14, p=0.5)$; while in $\mathrm{JU}$ reservoir this relation was significant $(y=-24131.9+1826.3, r=0.67, p=0.001)$.

\section{Discussion}

Early warning is an essential tool for reducing the damage caused by the invasion of zebra mussels (Hosler, 2011). Sampling collection using plankton nets off riverbanks is able to detect larvae when they first appear in the water, at low densities and in rapidly changing environments. The effectiveness of this technique is based on the fact that there is a greater production of larvae in shallow areas, including submerged vegetation (Sullivan et al., 2010), and around floating objects close to the riverbank. These are the areas where larvae can be detected before they start to occupy pelagic zones. In addition, it has been confirmed in Ebro river that veliger larvae prefer tend to remain preferably in the most illuminated area. This is similar to what has been observed for adult animals which exhibit positive phototatic behavior during aggregate formation (Koback, 2001; Toomey et al., 2002; Tosënovsky and Kobak, 2016). Hence, the banks of reservoirs are ideal places for monitoring the early presence of D. polymorpha, in both larval and adult phases, especially during the onset of the invasion and before the establishment of populations in deeper areas.

The samples collected by filtering small amounts of water can also detect the changes in density that occur between areas with deep pools (with lenitic dynamics) and a strong current (with lotic dynamics), where the larvae are carried away by the current. By contrast, these samples on the banks are not sensitive to the detection of plantigrade larvae capable of fixing themselves to substrate. However, submerged shoreline cores provide a reliable and sensitive alternative to mussel strings suspended from buoys (CHJ, 2017) in deep waters for early warning.

Fewer larvae were detected in station E1 than in E2, despite the fact that there was less turbulence in the water and that the possible reception area for larvae derived from upstream populations. Although the flow is the dispersion system most of the D-veliger forms transported in this way are not very effective in establishing new populations; they continue with metamorphosis but the mortality rate greatly increases (Lucy et al., 2008). Horvath and Lamberti (1999) estimate that $40 \%$ of larvae survive at a distance of $18 \mathrm{~km}$ along the riverbed, when $95 \%$ survive on the invasion's focus. In addition, turbulence in rapid currents may cause larval mortality (Rehmann et al., 2003; Horvath and Crane, 2010), but can also be advantageous to adult animals because of the constant water flow (Beisel et al., 2010; Sanz-Ronda et al., 2013). The alterations produced by the reservoirs in the hydrodynamics of the rivers promote the stagnant waters, operating as fluvial lakes of regular flow, enabling it to reproduce during long time periods to the year.

In reservoirs fluvial-lake typology there are significant differences that must be taken into account when collecting samples near banks, such as if the spot is sunny or shade, although the water temperature is homogeneous. In submerged banks, the granulometry of the bottom substrate and the river flow are key factors for the successful establishment of zebra mussels populations (Karatayev et al., 1998), as areas with fine granulometry or moving gravel are not favorable for pediveliger larvae. But the rocks in the canyon walls are suitable for settlement and although during sampling season the adults are submerged mainly at 3-5 m (Stańczykowska and Lewandowski, 1993), veligers are captured on the surface due to their phototaxia (Koback, 2001; Koback and Nowacki, 2007) also being correctly sampled on the banks.

Sprung (1993) has compiled studies from central Europe where the first appearance of larvae in the water is marked by a threshold temperature close to $14^{\circ} \mathrm{C}$ (range $12-21^{\circ} \mathrm{C}$ ). Viable larvae were detected in $\mathrm{JU}$ with a temperature greater than $13.8^{\circ} \mathrm{C}$, from 20 March to 14 November. However, the high mortality rate of the post-veliger phases would be higher in the colder autumn waters $\left(<18^{\circ} \mathrm{C}\right)$ and more difficult for the mussels to become fixed to the substrate (Koback, 2006). Despite this, several spawning periods were shown to occur in the autumn of each year (Borcherding, 1991; Nichols, 1996) in the different populations studied, especially in the Júcar River, producing several combined juvenile cohorts with sizes $<9-12 \mathrm{~mm}$ (ages 0+ according to Smit et al., 1993; Beisel et al., 2010). Therefore, the quality of water (nutrients and primary production) seems less important for the invasion of reservoirs in Mediterranean environments than water temperature that allows its larval development during more months than in other well-known populations. Therefore, the simplification of the microscopic counts of aliquots facilitates monitoring. Scientific approaches and optimization of monitoring surveys employed in each basin to prevent the expansion through human activities (Durán and Anadón, 2008; Durán et al., 2010; Minchin et al., 2003).

In Spain, it is not known to what extent the awarenessraising programs that warn about the economic and ecological dangers caused by zebra mussels, the attitudes and behaviors of citizens in relation to this and other biological invasions have changed (Strayer, 2009). There are still numerous gaps in strategies to halt the establishment and reduce the impacts of freshwater NIS which cause biofouling, as their progress is unceasing throughout the Mediterranean area.

In this sense, it would be interesting to carry out, for example, the early detection of larvae in continuous from the evolution of the water temperature and not by seasonal surveys. It is also necessary to take into account the possibility of more intensive monitoring from banks, in both rivers and deep reservoirs, instead of using only planktonic samples and buoy-suspended core samples. Simple and easy sample collection methods, like the one carried out by from the river bank, can also provide good information. Moreover, the inclusion of differing environmental condition, such as lotic versus lenitic or sunny versus shady banks within fluvial canyons, in the design of monitorization campaigns, can improve the accuracy of the data collected and optimize management decisions through earlier and safer responses.

\section{Supplementary material}

Supplementary material 1. Changes in water flow rate during the last decades for each study area considered; positive and negative values with respect to the average of the complete data series. 
Supplementary material 2. Differences in the estimation of larval density in 2016 on Cortes II reservoir (JU1 and JU2), using two microscopically recounting methods (Met1 and Met2).

Supplementary material 3. Linear regression model between the two microscopic counting methods for the larval density of the two areas of the Júcar Canyon (JU1 suntrap, JU2 shady).

The Supplementary Material is available at https://www.kmaejournal.org $/ 10.1051 / \mathrm{kmae} / 2018042 / \mathrm{olm}$.

Acknowledgements. The project was funded by the IBERDROLA's Chair on the University of Salamanca within the cooperation projects (2009-2016) in powerplants of Castejón de Ebro and Cortes II-La Muela. The temperature and flow data were taken from the hidrological official datagaugin networks in Spain, respectively, hidrological authority of river Ebro (CHE) and Júcar (CHJ). The authors thank Ms. E.J. Keck for the revision of the English version of the manuscript.

\section{References}

Ackerman JD, Sim B, Nichols SJ, Claudi R. 1994. A review of the early life history of zebra mussels (Dreisssena polymorpha): Comparisons with marine bivalves. Can J Zool 72: 1169-1179.

Araujo R. 2006. La afección del mejillón cebra y su posible lucha en las infraestructuras, especialmente en los riegos tradicionales y modernizados del Levante Ibérico. Unpublished report, 42 pp. [in Spanish]. https://www.chj.es/ (accessed March, 2018).

Araujo R. 2007. Detección de formas larvarias de Dreissena polymorpha, mejillón cebra, en los embalses del ámbito de la Confederación Hidrográfica del Júcar. Unpublished report, 10 pp [in Spanish]. https://www.chj.es/ (accessed March, 2018).

Araujo R, Valladolid M, Gómez I. 2010. Life cycle and density of a newcomer population of zebra mussels in the Ebro River, Spain. In: van der Velde G, Rajagopal S, bij de Vaate A, eds. The Zebra Mussel in Europe. Leiden, The Netherlands: Backhuys Publishers, pp. $183-189$.

Armistead DC. 1995. Tolerances of zebra mussels to various temperatures in the Mississippi and Ohio rivers, 1988-1992. Zebra Mussel Research, Section 1-Environmental Testing. Technical Notes ZMR-1-32, 6 pp.

Beisel JN, Bachmann V, Moreteau JC. 2010. Growth-al-length model and related life-history traits of Dreissena polymorpha in lotic ecosystems. In: van der Velde G, Rajagopal S, bij de Vaate A, eds. The Zebra Mussel in Europe. Leiden, The Netherlands: Backhuys Publishers, pp. 191-197.

Bernat Y, Durán C, Viamonte A. 2010. The zebra mussel in Spain: Management strategies to prevente its spread. In: van der Velde G, Rajagopal S, bij de Vaate A, eds. The Zebra Mussel in Europe. Leiden, The Netherlands: Backhuys Publishers, pp. 403-413.

Borcherding J. 1991. The annual reproductive cycle of the freshwater mussel Dreissena polymorpha Pallas in lakes. Oecologia 87: 208-218.

CHJ. 2015. Seguimiento de la evolución de la población de mejillón cebra (Dreissena polymorpha) en la cuenca del río Júcar. Informe anual de resultados 2014, Unpublished report, 24 pp. [in Spanish]. https://www.chj.es/ (accessed March, 2018).

CHJ. 2017. Control y seguimiento del mejillón cebra en el ámbito de la Demarcación Hidrográfica del Júcar. Informe de actuaciones 2017. Unpublished report, 56 pp. [in Spanish] https://www.chj.es/ (accessed March, 2018).
Cohen AN, Wenstein A. 2001. Zebra mussel's calcium threshold and implications for its potential distribution in North America. $44 \mathrm{pp}$. http://www.sfei.org/sites/default/files/2001-Zebramusselcal cium356.pdf (accessed March, 2018).

Durán C, Anadón A. 2008. The zebra mussel invasion in Spain and navigation rules. Aquat Invasions 3: 315-324.

Durán C, Lanao M, Anadón A, Touyá V. 2010. Management strategies for the zebra mussel invasion in the Ebro River basin. Aquat Invasions 5: 309-316.

Durán C, Lanao M, Pérez L, Chica C, Anadón A, Touya V. 2012. Estimación de los costes de la invasión del mejillón cebra en la cuenca del Ebro (periodo 2005-2009). Limnetica 31: 213-230.

EEA - European Environment Agency. 2012. Streamlining European biodiversity indicators 2020: Building a future on lessons learnt from the SEBI 2010 process. EAA Technical Report No 11/2012 EEA. http://www.eea.europa.eu/ (accessed January, 2018).

Griebeler EM, Seitz A. 2007. Effects of increasing temperatures on population dynamics of the zebra mussel Dreissena polymorpha: implications from an individual-based model. Oecologia 151: 530-543.

Hincks SS, Mackie GL. 1997. Effects of pH, calcium, alkalinity, hardness, and chlorophyll on the survival, growth, and reproductive success of zebra mussel (Dreissena polymorpha) in Ontario lakes. Can J Fish Aquat Sci 54: 2049-2057.

Horvath TG, Crane L. 2010. Hydrodynamic forces affect larval zebra mussel (Dreissena polymorpha) mortality in a laboratory setting. Aquat Invasions 5: 389-375.

Horvath TG, Lamberti GA. 1999. Mortality of zebra mussel, Dreissena polymorpha, veligers during downstream transport. Freshwater Biol 42: 69-76.

Hosler DM. 2011. Early detection of dreissenid species: zebra/quagga mussels in water systems. Aquat Invasions 6: 217-222.

Hulme P. 2007. Biological invasions in Europe: drivers, pressures, states, impacts and responses. In: Hester RE, Harrison RM, eds. Biodiversity Under Threat, Issues in Environmental Science and Technology no 25. Cambridge: Royal Society of Chemistry, pp. $56-80$.

Johnson LE. 1995. Enhanced early detection and enumeration of zebra mussel (Dreissena spp.) veligers using cross-polarized light microscopy. Hydrobiologia 312: 139-146.

Jones LA, Ricciardi A. 2005. Influence of physicochemical factors on the distribution and biomass of invasive mussels (Dreissena polymorpha and Dreissena bugensis) in the St. Laurence River. Can J Fish Aquat Sci 62: 1953-1962.

Karatayev AL, Burlakova LE, Padilla DK. 1998. Physical factors that limit the distribution and abundance of Dreissena Polymorpha (Pall.). J Shellfish Res 17: 1219-1235.

Keller RP, Geist J, Jeschke JM, Khün I. 2011. Invasive species in Europe: ecology, status, and policy. Environ Sci Eur 23: 23.

Koback J. 2001. Ligth, gravity and conspecifics as cues to site selection and attachment behaviour of juvenile and adult Dreissena polymorpha Pallas, 1771. J Molluscan Stud 67: 183-189.

Koback J. 2006. Factors influencing the attachment strength of Dreissena polymorpha (Bivalvia). Biofouling 22: 141-150.

Koback J, Nowacki P. 2007. Light-related behaviour of the zebra mussel (Dreissena polymorpha, Bivalvia). Fund Appl Limnol Arch Hydrobiol 169: 341-352.

Lowe S, Browne M, Boudjelas S, De Poorter M. 2000. 100 of the World's Worst Invasive Alien Species. A selection from the Global Invasive Species Database. Published by The Invasive Species Specialist Group (ISSG) of IUCN, 12 pp. http://www.issg.org/pdf/ publications/worst_100/english_100_worst.pdf (accessed March, 2018). 
Lucy F, Minchin D, Boelens R. 2008. From lakes to rivers: downstream larval distribution of Dreissena polymorpha in Irish river basins. Aquat Invasions 3: 297-304.

Mackie GL, Schloesser DW. 1996. Comparative biology of zebra mussels in Europe and Norh America: an overview. Integr Comp Biol (Am Zool) 36: 244-258.

MARM. 2009. Estrategia Nacional para el control del mejillón cebra (Dreissena polymorpha) en España. [National strategy to control the zebra mussel (Dreissena polymorpha) in Spain]. Ed. Ministerio de Medio Ambiente y Medio Rural y Marino, Madrid, Spain, 45 pp. (in Spanish). www.mapama.gob.es/ (accessed January, 2018).

Minchin D, Maguire C, Rosell R. 2003. The zebra mussel (Dreissena polymorpha pallas) invades ireland: human mediated vectors and the potential for rapid intranational dispersal. Biol Environ: Proc $R$ Irish Acad 103B: 23-30.

Morales JJ, Flechoso F, Lizana M, Negro A. 2013. Patrones de colonización y ecología de poblaciones de dos bivalvos invasores (Dreissena polymorpha Pallas, 1771 y Corbicula fluminea Müller, 1774) en un tramo lótico del Ebro medio (Castejón, Navarra). Munibe 61: 47-69. (In Spanish).

Naddafi R, Blenckner T, Eklöv P, Pettersson K. 2011. Physical and chemical properties determine zebra mussel invasion success in lakes. Hydrobiologia 669: 227-236.

Nichols SJ. 1993. Spawning zebra mussel (Dreissena polymorpha) and rearing of veligers under laboratory conditions. In: Nalepa TF, Scholesser DW, eds. Zebra Mussels: Biology, Impacts and Control. Boca Raton: Lewis Publishers, pp. 315-329.

Nichols SJ. 1996. Variations in the reproductive cycle of Dreissena Polymorpha in Europe, Russia, and North America. Integr Comp Biol (Am Zool) 36: 311-325.

Nichols SJ, Black MG. 1994. Identification of larvae: The zebra mussel (Dreissena polymorpha), quagga mussel (Dreissena rosteriformis bugensis), and the Asian Clam (Corbicula fluminea). Can J Zool 72: 406-417.

Olson J, Robertson JJ, Swannack TM, McMahon RF, Nowlin WH, Schwalb AN. 2018. Dispersal of zebra mussels (Dreissena polymorpha) downstream of an invaded reservoir. Aquat Invasions 3: 199-209.

Oscoz J, Tomás P, Durán C. 2010. Review and new records of nonindigenous freshwater invertebrates in the Ebro River basin (Northeast Spain). Aquat Invasions 5: 263-284.

Pérez L, Chica C. 2010. Actualización de la valoración económica de la invasión del mejillón cebra en la Cuenca del Ebro. Confederación Hidrográfica del Ebro, Área de Calidad Ambiental, Ministerio de Medio Ambiente, Medio Rural y Marino, Zaragoza, 90 pp. www.chebro.es/ (accessed January, 2018).

Petts GE, Amoros C. 1996. Fluvial Hydrosystems. London: Chapman and Hall Ltd, 322 pp.

Rehmann CR, Stoeckel JA, Schneider DW. 2003. Effect of turbulence on the mortality of zebra mussel veligers. Can J Zool 81: 10631069.

Rodríguez D, Morales JJ, Flechoso F, Sánchez JA, Negro A, Lizana M. 2017. On the distribution and general abundance of non-native species associated with the Ebro river (Castejón, Navarra, NE Spain). Russ J Biol Invasions 8: 189-196.

Sanz-Ronda FJ, López-Sáenz S, San-Martín R, Palau-Ibars A. 2013. Physical habitat of zebra mussel (Dreissena polymorpha) in the lower Ebro River (Northeastern Spain): influence of hydraulic parameters in their distribution. Hydrobiologia 735: 137-147.
Savini D, Occhipinti-Ambrogi A, Marchini A, Tricarico E, Gherardi F, Olenin S, Gollasch S. 2010. The top 27 animal alien species introduced into Europe for aquaculture and related activities. $J$ Appl Ichthyol 26: 1-7.

Schneider DW. 1992. A bioenergetic model of zebra mussel, Dreissena polymorpha, growth in the Great Lakes. Can J Fish Aquat Sci 49: 1406-1416.

Smit H, bij de Vaate A, Reeders HH, van Nes E, Noordhuis R. 1993. Colonization, ecology, and positive aspects of zebra mussels (Dreissena polymoprha) in The Netherlands. In: Nalepa TF, Schloesser DW, eds. Zebra Mussels: Biology, Impacts and Control. Boca Raton, FL: CRC Press, pp. 55-77.

Sprung M. 1987. Ecological requirements of developing Dreissena polymorpha eggs. Arch Hydrobiol Supplementband Monographische Beiträge 79: 69-86.

Sprung M. 1989. Field and laboratory observations of Dreissena polymorpha larvae: abundance, growth, mortality and food demands. Arch Hydrobiol 115: 537-561.

Sprung M. 1993. The other life: An account of present knowledge of the larval phase of Dreissena polymorpha. In: Nalepa TF, Schloesser DW, eds. Zebra Mussels: Biology, Impacts and Control. Boca Raton, FL: CRC Press, pp. 39-53.

Stańczykowska A, Lewandowski K. 1993. Thirty years of studies of Dreissena polymorpha ecology in Mazurian lakes of Northeastern Poland. In: Nalepa TF, Schloesser DW, eds. Zebra Mussels: Biology, Impacts and Control. Boca Raton, FL: CRC Press, pp. 3-33.

Stoeckel JA, Rehmann CR, Schneider DW, Padilla DK. 2004. Retention and supply of zebra mussel larvae in a large river system: importance of an upstream lake. Freshwater Biol 49: 919-930.

Strayer DL. 2009. Twenty years of zebra mussels: lessons from the mollusk that made headlines. Front Ecol Environ 7: 135-141.

Sullivan M, Lucy F, Minchin D. 2010. The association between zebra mussels and aquatic plants in the Shannon River system in Ireland. In: Van der Velde G, Rajagopal S, Bij de Vaate A, eds. The zebra mussel in Europe. Leiden, The Netherlands: Backhuys Publishers, pp. 211-218.

Toomey MB, McCabe D, Marsden JE. 2002. Factors affecting the movement of adult zebra mussels (Dreissena polymorpha). J North Am Benthol Soc 21: 468-475.

Tosënovsky E, Kobak J. 2016. Impact of abiotic factors on aggregation behaviour of the zebra mussel Dreissena polymorpha. J Molluscan Stud 82: 55-66.

USAL - Salamanca University. 2014. Seguimiento de la incidencia del mejillón cebra (Dreissena polymorpha) en el ciclo combinado de Castejón, periodo 2009-2013. [Monitoring the impact of zebra mussels on the combined cycle power plant ofCastejón, period 20092013]. Lizana M (Coord) Unpublished report, 305 pp. (In Spanish).

USAL - Salamanca University. 2018. Asistencia técnica para evaluar la incidencia del mejillón cebra en la central hidroeléctrica de La Muela y el embalse de Cortes II (río Júcar). [Monitoring the impact of zebra mussels on the hidropower plant La Muela and Cortes II reservoir, period 2016-2017]. Lizana M (Coord) Unpublished report, 65 pp. (In Spanish).

Utermöhl H. 1958. Zur vervollkommnung der quantitativen phytoplankton-methodik. Mitteilungen. Internationale Vereiningung fuer Theoretische und Angewandte. Limnologie 9: 1-38.

Yu N, Culver DA. 1999. In situ survival and growth of zebra mussels (Dreissena polymorpha) under chronic hypoxia in a stratified lake. Hydrobiologia 392: 205-215.

Cite this article as: Morales J, Lizana M, Flechoso F, Bejarano GM, Negro AI. 2019. Estimate zebra mussel veliger density from the riverbanks, lotic stretch and reservoir, in two Mediterranean rivers (E Spain). Knowl. Manag. Aquat. Ecosyst., 420, 7 